\title{
Transient Hypogonadism Induced by SARS-CoV-2 during COVID-19 in Men Aged under 65 Years
}

\author{
Etoa Etoga Martine Claude ${ }^{1,2 *}$, Biwole Sida Ghislaine ${ }^{1,2}$, Ama Moor Vicky ${ }^{3}$, Ongmeb Boli Anne², \\ Ndi Manga Jean Arnaud², Dehayem Yefou Mesmin',2, Mendane Mekobe Francine1, \\ Jean Claude Mbanya1,2, Sobngwi Eugène ${ }^{1,2}$
}

\author{
${ }^{1}$ Department of Internal Medicine and Specialties, Faculty of Medicine and Biomedical Sciences, University of Yaoundé 1, \\ Yaoundé, Cameroon \\ ${ }^{2}$ Endocrinology and Metabolic Diseases Unit, Yaoundé Central Hospital, Yaoundé, Cameroon \\ ${ }^{3}$ Department of Physiologic Sciences and Biochemistry, Faculty of Medicine and Biomedical Sciences, University of Yaoundé 1, \\ Yaoundé, Cameroon \\ Email: *claudetoa@yahoo.fr
}

How to cite this paper: Claude, E.E.M., Ghislaine, B.S., Vicky, A.M., Anne, O.B., Arnaud, N.M.J., Mesmin, D.Y., Francine, M.M., Mbanya, J.C. and Eugène, S. (2022) Transient Hypogonadism Induced by SARSCoV-2 during COVID-19 in Men Aged under 65 Years. Open Journal of Endocrine and Metabolic Diseases, 12, 1-8. https://doi.org/10.4236/ojemd.2022.121001

Received: November 20, 2021

Accepted: January 16, 2022

Published: January 19, 2022

Copyright (c) 2022 by author(s) and Scientific Research Publishing Inc. This work is licensed under the Creative Commons Attribution International License (CC BY 4.0)

http://creativecommons.org/licenses/by/4.0/ (c) (i) Open Access

\begin{abstract}
Background: The presence of the angiotensin-converting enzyme 2 (ACE2) receptor, the main entry receptor for SARS-CoV-2 in lung alveolar tissue, in Sertoli and Leydig cells of the adult testis, may suggest possible testicular involvement during SARS-CoV-2 infection. Our aim was to investigate the impact of COVID-19 on gonadal function in men. Methods: This was a crosssectional descriptive and analytical study in a population of men aged below 65 years of age with SARS-CoV-2. Not included in the study were any subjects on testosterone replacement therapy or with a known condition that could create hypogonadism. We recruited patients through a questionnaire and then performed total testosterone and SHBG analysis at 8 hours and 2 months post infection by ELISA. We used the Spearman Rho test for statistical analysis of correlations. The significance level was set at 0.05 . Results: The sample consisted of 40 male COVID positive patients with a mean age of $46.4 \pm 11.8$ years. Eight patients were reviewed after infection. The mean total testosterone was $11 \mathrm{ng} / \mathrm{ml} \pm 2.4$ and the SHBG was $113 \mathrm{nmol} / 1 \pm 66.9$ during infection. In the 8 patients reviewed after infection, median total testosterone decreased during infection $(11 \mathrm{ng} / \mathrm{ml})$ and increased after infection $(12.7$ $\mathrm{ng} / \mathrm{ml})$, this result was statistically significant $(\mathrm{P}=0.028)$. Median SHBG during infection was increased $(115.7 \mathrm{nmol} / \mathrm{l})$ and after infection was decreased $(82 \mathrm{nmol} / \mathrm{l})$. There was a statistically significant $(\mathrm{P}=0.04)$ and positive correlation between serum testosterone and SHBG levels in patients with severe infection. Conclusion: There could be a transient relative hypogonadism during SARS-CoV-2 infection, more marked in the severe forms of the disease with a tendency to improve after infection.
\end{abstract}




\section{Keywords}

COVID-19, Testosterone, Severity

\section{Introduction}

Although COVID-19 is a disease with respiratory onset, it may evolve to a systemic level with multi-organ involvement thus accounting for its variable symptomatology. The clinical manifestations of SARS-CoV-2 infection appear to be broad, ranging from asymptomatic infection, mild upper respiratory tract disease, to severe viral pneumonia with respiratory failure during the $2^{\text {nd }}$ or $3^{\text {rd }}$ week of infection [1]. SARS-CoV-2 infects pulmonary alveolar epithelial cells using the angiotensin-converting enzyme 2 (ACE2) receptor as its entry receptor [2]. ACE2 is also a constituent product of Leydig and Sertoli cells in the adult testis. Thus, the presence of this ACE2 receptor in both cells could favor tropism of SARS-CoV-2 for testicular tissue, suggest possible involvement of the testis during COVID-19 and hence its effect on testosterone production in infected men [3]. In addition, there is evidence that the entire population with SARS-CoV-2 is predominantly male. This trend could be attributed to a more responsive and robust immune system in women, due to estrogen modulating the immune system to protect women from severe inflammation [4]. The interest of this work was to determine the impact of COVID-19 on testicular function and assess its association with disease severity.

\section{Methodology}

\subsection{Type of Study}

We conducted a descriptive and analytical cross-sectional study at the COVID-19 unit of the Yaoundé Central Hospital in Cameroon. The study was conducted over a period of 5 months, from May 2020 to September 2020.

Inclusion criteria: We included men confirmed positive for SARS-CoV2 and aged between 21 and 65 years who gave their informed consent.

Exclusion criteria: Any subject with known hypogonadism or on therapy that may affect gonadal function was excluded.

Sampling was consecutive, exhaustive and non-probability.

\subsection{Procedure}

Patient information was obtained from the medical records of the included patients. We recorded age, sex, comorbidities, clinical presentation, room air oxygen saturation, and initiation of oxygen therapy. Patients were seen twice during the study: during and 2 months after infection. During these two phases, patients were sampled at 8:00 am for total testosterone and SHBG by competitive ELISA and Sandwich ELISA, respectively, according to laboratory procedures. 
The biological data were interpreted as follows:

Total testosterone ranging from $3-12 \mathrm{ng} / \mathrm{ml}$ in adult males was considered to have normal gonadal function. Patients with a serum total testosterone value of less than $3 \mathrm{ng} / \mathrm{ml}$ were considered to have true hypogonadism. SHBG values were defined according to the standards set by the French Urology Agency, with normal values ranging from $13-71 \mathrm{nmol} / \mathrm{l}$ in adult men. We considered any patient above this standard as having relative hypogonadism [5].

\subsection{Statistical Analyses}

Data were processed and analyzed using SPSS version 26.0 and Excel. Descriptive analyses were used for socio-demographic data and clinical characteristics. Quantitative variables were expressed as means, with standard deviation. For the study of correlations, we first classified the patients into 2 groups according to the severity of the infection: one group under oxygen therapy and the other without oxygen therapy. Then we looked for correlations between SHBG and testosterone of the patients using Spearman's Rho correlation. The threshold of statistical significance was set at a value of $\mathrm{p}<0.05$. We obtained an ethical clearance from the Institutional Research and Ethics Committee of the Université des Montagnes (2020/057/UdM/PR/CIE).

\section{Results}

At inclusion 40 patients gave their informed consent to participate in the study and were sampled during infection. Two months after infection, 8 patients responded to the call for a second follow-up sample and the remaining 32 were lost to follow-up.

1) Characteristics of the study population

The average age of the participants was $46.4 \pm 11.8$ years, with extremes of 22 and 63 years. The most represented age group was [36;55] years $(50 \%)$

\section{- Distribution of the study population according to comorbidities}

The most frequent comorbidity was arterial hypertension in $15 \%$ of cases, followed by diabetes (12.5\%) and finally obesity and HIV infection in equal proportions (12.5\%).

\section{- Distribution of patients according to clinical symptoms}

During the infection, most patients experienced a decrease in libido (75\%). The most frequent general symptoms were asthenia (67.5\%) and fever (45\%), followed by respiratory signs such as cough (60\%) and finally ear, nose and throat (ENT) and digestive symptoms.

- Distribution of patients on oxygen therapy and without oxygen therapy

We had a total of 09 patients on oxygen therapy versus 31 who were not on oxygen therapy at the onset of the COVID-19 infection.

\section{2) Biological data}

\section{- Biological values during the infection.}

During infection, mean total testosterone was $11 \pm 2.4 \mathrm{ng} / \mathrm{ml}$ with a minimum 
of $4.6 \mathrm{ng} / \mathrm{ml}$ and a maximum of $27 \mathrm{ng} / \mathrm{ml}$ and the median at $11 \mathrm{ng} / \mathrm{ml}$. The mean SHBG was $113 \pm 66.9 \mathrm{nmol} / \mathrm{l}$, with a minimum of 16.5 and a maximum of 283.7 $\mathrm{nmol} / \mathrm{l}$ and a median during infection increased to $115.7 \mathrm{nmol} / \mathrm{l}$. However, 34/40 patients had an increased SHBG compared to the threshold value (Table 1 and Table 2).

\section{- Biological values 2 months after infection:}

Eight of the 40 participants at inclusion were reviewed after infection. Median total testosterone increased from $11 \mathrm{ng} / \mathrm{ml}$ during infection to $12.7 \mathrm{ng} / \mathrm{ml}$ after infection.

Median SHBG during infection decreased from $115.7 \mathrm{nmol} / \mathrm{l}$ to $82 \mathrm{nmol} / \mathrm{l}$ after infection (Figure 1 and Figure 2).

Table 1. Total testosterone and SHBG levels within the study population.

\begin{tabular}{cccc}
\hline Variables & Means \pm SD & Minimum & Maximum \\
\hline Total testosterone $(\mathrm{ng} / \mathrm{ml})$ & $11.08 \pm 2.48$ & 4.60 & 27 \\
SHBG $(\mathrm{nmol} / \mathrm{l})$ & $113.68 \pm 66.93$ & 16.50 & 283.75 \\
\hline
\end{tabular}

Table 2. Total testosterone and SHBG levels within the study population.

\begin{tabular}{clccc}
\hline \multicolumn{2}{c}{ Variables } & Mediane & Interquartile & P value \\
\hline \multirow{2}{*}{ Testosterone } & During Covid & 38.14 & {$[35.54 ; 40.75]$} & \\
& After & 44.04 & {$[41.96 ; 48.37]$} & 0.028 \\
\multirow{2}{*}{ SHBG } & During Covid & 115.7 & {$[102 ; 242.25]$} & \multirow{2}{*}{0.063} \\
& After & 82 & {$[63 ; 118]$} & \\
\hline
\end{tabular}

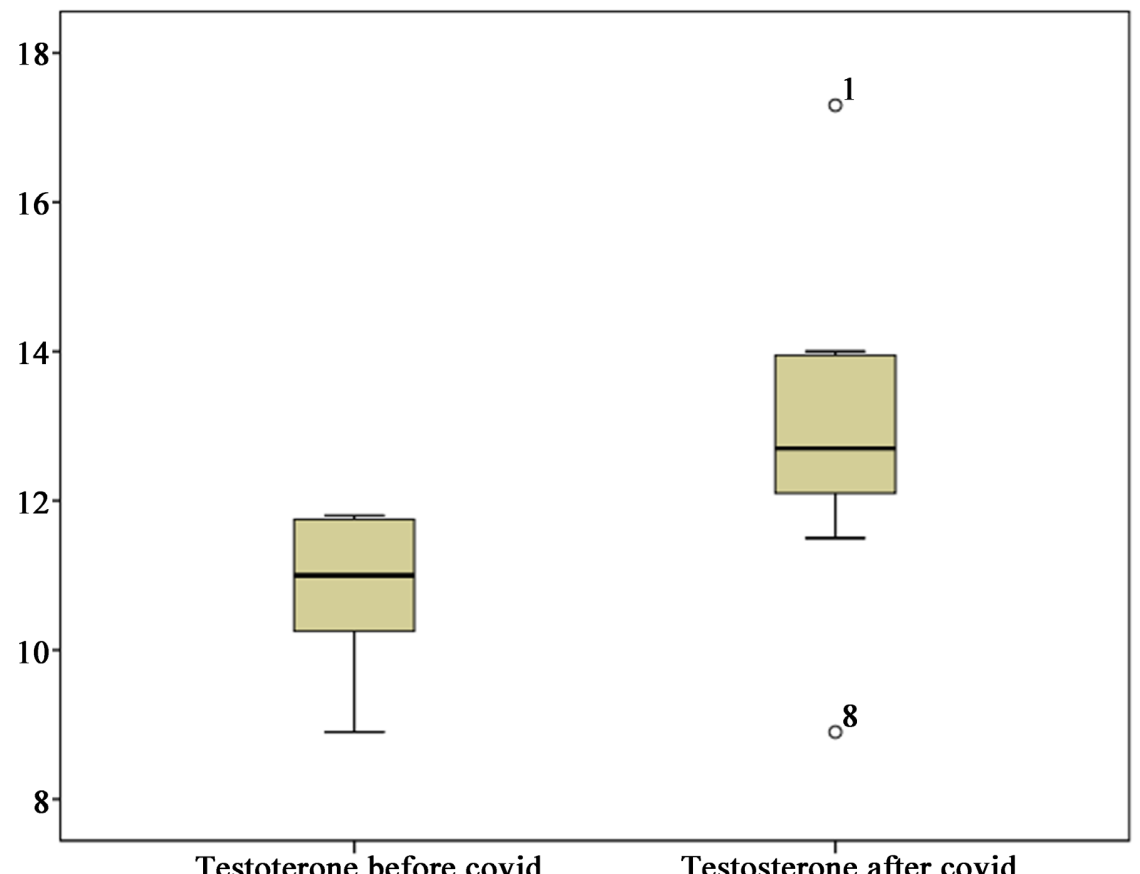

Figure 1. Comparison of testosterone levels during and after infection $(n=8)$. 


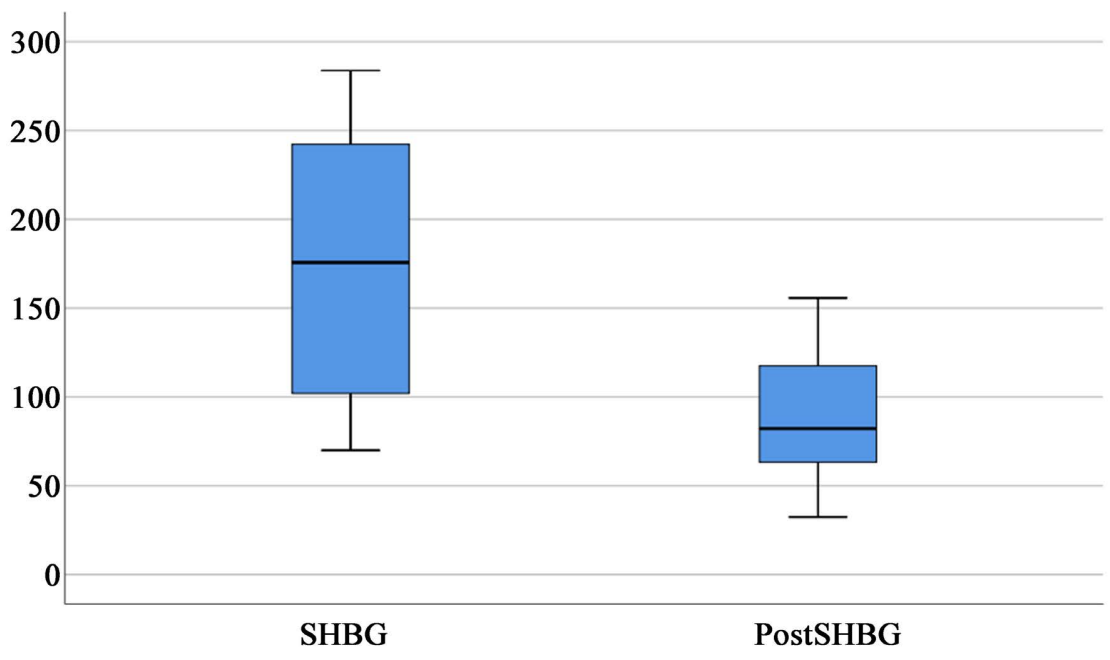

Figure 2. Comparison of SHBG levels during and after infection $(n=8)$.

Table 3. Correlation between SHBG and testosterone in patients with oxygen.

\begin{tabular}{ccc}
\hline Testosterone & Spearman Rho & P value \\
\hline SHBG & 0.68 & 0.040 \\
\hline
\end{tabular}

Table 4. Correlation between SHBG and testosterone in patients without oxygen.

\begin{tabular}{ccc}
\hline Testosterone & Spearman Rho & P value \\
\hline SHBG & 0.14 & 0.43 \\
\hline
\end{tabular}

\section{3) Correlation study}

\section{- Correlation between SHBG and testosterone in oxygen-treated patients}

There was a statistically significant $(\mathrm{P}=0.04)$, moderate positive correlation between serum testosterone and SHBG levels in oxygen-treated patients (Table 3).

\section{- Correlation between SHBG and testosterone in non-oxygenated patients}

There was no statistically significant correlation between SHBG and testosterone in patients who had not been on oxygen therapy (Table 4).

\section{Discussion}

The aim of the study was to evaluate the impact of COVID-19 on testicular function in a group of men aged 21 - 65 years. During the study 40 patients were recruited and only 8 agreed to return for a check-up 2 months after infection. In addition, we were unable to have a control population to compare testosterone levels in healthy versus affected patients. It should be noted that the study was conducted during the $1^{\text {st }}$ wave of SARS-CoV-2 infection. Many of the patients reported to be cured as well as the uninfected individuals did not want to have any further contact with the hospital setting. This high drop-out rate could be a limitation for the assessment of gonadal function after infection, but the value of 8 participants already gives us a trend of this evolution. In our study, each par- 
ticipant was his own control. Our results show that the mean total testosterone level of the study population was $11.08 \pm 2.48 \mathrm{ng} / \mathrm{ml}$ with a minimum of 4.60 and a maximum of 27 . While the mean SHBG was $113 \pm 66.93 \mathrm{nmol} / \mathrm{ml}$ with a minimum of 16.50 and a maximum of 283.75 . However, 34 patients in the sample had increased SHBG compared to the reference value of $13-71 \mathrm{nmol} / \mathrm{l} \mathrm{ac}$ cording to the French Society of Urology [5]. When comparing 08 participants who were reviewed after infection, we observed that median total testosterone decreased during infection $(11 \mathrm{ng} / \mathrm{ml})$ and increased after infection $(12.7 \mathrm{ng} / \mathrm{ml})$.

In contrast to studies that described a low free testosterone levels among men with severe forms of COVID 19 [6], free testosterone levels remained within normal levels in our study. Notwithstanding this finding, the free testosterone levels dropped during infection as compared to the post-infection control $(\mathrm{P}=0.028)$.

Although these values remained at non-pathological thresholds, this result was statistically significant $(\mathrm{P}=0.028)$. SHBG during infection was increased $(115.7 \mathrm{nmol} / \mathrm{l})$ and after infection was decreased $(82 \mathrm{nmol} / \mathrm{l})$ but still remained at a pathological threshold. There was a positive correlation between total testosterone and SHBG in patients on oxygen while in the absence of oxygen therapy there was no correlation between total testosterone and SHBG.

Regarding the gonadal function of our patients, although the mean testosterone was normal, 34 patients had an increased SHBG of more than $71 \mathrm{nmol} / \mathrm{L}$. This is because SHBG, the sex steroid transporter protein, binds with high affinity to testosterone and consequently decreases the free fraction, which is the active form and is responsible for the effects of testosterone on the cells of the body. Thus, an increase in SHBG to the $71 \mathrm{nmo} / \mathrm{l}$ threshold will be considered as a state of hypogonadism in our patients, as attested by the French Urological Association [5]. Likewise, a retrospective study carried out in Wuhan in 2020 on a population of men infected with SARS-Cov-2 showed an increased level of LH, with a normal plasma testosterone level but a significantly reduced testosterone/LH ratio. These results suggested to the authors an early stage of primary hypogonadism [7]. This is because at an early stage, abnormal testicular production of testosterone can stimulate the release of LH to temporarily maintain testosterone levels.

We also established correlations between SHBG and testosterone in patients who were on oxygen therapy. There was a statistically significant $(\mathrm{P}=0.04)$ and positive correlation between serum total testosterone and SHBG levels in patients who had been on oxygen therapy. Meaning that the more severe the disease, requiring oxygen, the higher the SHBG and total testosterone and the lower free active testosterone. These observations are consistent with those of Cayang et al. [8] who found that as serum total testosterone levels decreased, the likelihood of the patient being in the intensive care unit increased significantly, same as the likelihood of mortality. Furthermore, this decrease in testosterone secretion could be explained by the fact that SARS-CoV-2 enters and infects Leydig cells using angiotensin converting enzyme 2 (ACE2) which is a constituent prod- 
uct of adult Leydig cells, and therefore decreases testosterone secretion as demonstrated by Hoffman et al. [2].

On the contrary, Van Zeggeren et al. in Amsterdam reported that lower levels of total and free testosterone were associated with fatal outcome in men who died of COVID-19, as were lower levels of SHBG in both men and women in a retrospective study including 40 patients [9].

Furthermore, a study by Maggio et al. indicates that pro-inflammatory cytokines, notably IL-6, IL-1 beta and TNF alpha, inhibit testosterone secretion through their influence on the central (hypothalamic-pituitary) and peripheral (testicular) components of the gonadal axis. This gives a clue to the state of hypogonadism that could occur during COVID-19 infection as a result of the cytokine storm observed during this condition [10] [11]. This inflammatory state resulting from the cytokine storm, and its deleterious effect impact on testosterone secretion, could justify the reactive increase of SHBG during this infection, as was the case in our study population.

\section{Conclusion}

The high SHBG values found during SARS-CoV-2 infection could suggest a possible relative and transient hypogonadism without true alteration of the intra testicular testosterone production which occurs all the more in severe forms. This phenomenon, which seems to improve after infection, could be attributed to the inflammatory state present during COVID-19.

\section{Conflicts of Interest}

The authors declare no conflicts of interest regarding the publication of this paper.

\section{References}

[1] Adhikari, S., Meng, S., Wu, Y.-J., Mao, Y.-P., Ye, R.X. and Wang, Q.Z. (2020) Epidemiology, Causes, Clinical Manifestation and Diagnosis, Prevention and Control of Coronavirus Disease (COVID-19) during the Early Outbreak Period: A Scoping Review. Infectious Diseases of Poverty, 1, 29.

https://doi.org/10.1186/s40249-020-00646-X

[2] Hoffmann, M., Kleine-Weber, H., Krüger, N., Müller, M., Drosten, C. and Pöhlmann, S. (2020) The Novel Coronavirus 2019 (2019-nCoV) Uses the SARS-Coronavirus Receptor ACE2 and the Cellular Protease TMPRSS2 for Entry into Target Cells. BioRxiv, 929042. https://doi.org/10.1101/2020.01.31.929042

[3] Wang, Z. and Xu, X. (2020) scRNA-seq Profiling of Human Testes Reveals the Presence of the ACE2 Receptor, a Target for SARS-CoV-2 Infection in Spermatogonia, Leydig and Sertoli Cells. Cells, 4, 920. https://doi.org/10.3390/cells9040920

[4] Acheampong, D., Barffour, I., Boye, A., Aninagyei, E., Ocansey, S. and Morna, M. (2020) Male Predisposition to Severe COVID-19: Review of Evidence and Potential Therapeutic Prospects. Biomedicine \& Pharmacotherapy, 131, 110748. https://doi.org/10.1016/j.biopha.2020.110748

[5] Tostain, J., Rossi, D. and Martin, P.M. (2004) Déficit androgénique lié à l'âge et vieillissement masculin: Rapport du congrès 2004 de l'Association Française d'Urologie. Progrès en Urologie (Paris), 14, 639-660. 
[6] Schroeder, M., Schaumburg, B., Mueller, Z., Parplys, A., Jarczak, D. and Roedl, K. (2021) High Estradiol and Low Testosterone Levels Are Associated with Critical Illness in Male but Not in Female COVID-19 Patients: A Retrospective Cohort Study. Emerging Microbes \& Infections, 10, 1807-1818. https://doi.org/10.1080/22221751.2021.1969869

[7] Ma, L., Xie, W., Li, D.Y., Shi, L., Ye, G.M., Mao, Y.H., et al. (2021) Evaluation of Sex-Related Hormones and Semen Characteristics in Reproductive-Aged Male COVID-19 Patients. Journal of Medical Virology, 93, 456-462.

https://doi.org/10.1002/jmv.26259

[8] Cayan, S., Uguz, M., Saylam, B. and Akbay, E. (2020) Effect of Serum Total Testosterone and Its Relationship with Other Laboratory Parameters on the Prognosis of Coronavirus Disease 2019 (COVID-19) in SARS-CoV-2 Infected Male Patients: A Cohort Study. The Aging Male, 23, 1493-1503.

https://doi.org/10.1080/13685538.2020.1807930

[9] Van Zeggeren, I., Boelen, A., Van de Beek, D., Heijboer, A., Vlaar, A., Amsterdam UMC COVID-19 Biobank, et al. (2021) Sex Steroid Hormones Are Associated with Mortality in COVID-19 Patients: Level of Sex Hormones in Severe COVID-19. Medicine (Baltimore), 100, e27072. https://doi.org/10.1097/MD.0000000000027072

[10] Maggio, M., Basaria, A., Ceda, G., Ble, A. and Ling, S. (2005) The Relationship between Testosterone and Molecular Markers of Inflammation in Older Men. Journal of Endocrinological Investigation, 28, 116-119.

[11] Parolin, M., Parisotto, M., Zanchetta, F., Sartorato, P. and De Menis, E. (2021) Coronaviruses and Endocrine System: A Systematic Review on Evidence and Shadows. Endocrine, Metabolic \& Immune Disorders_Drug Targets, 21, 1242-1251. https://doi.org/10.2174/1871530320666200905123332

\section{Abbreviations}

$\begin{array}{ll}\text { ACE2 } & \text { Angiotensin 2 Converting Enzyme } \\ \text { RNA } & \text { Ribonucleic Acid } \\ \text { COVID-19 } & \text { Coronavirus Disease 2019 } \\ \text { OD } & \text { Optical Density } \\ \text { ELISA } & \text { Enzyme Linked Immunosorbent Assay } \\ \text { FSH } & \text { Follicle Stimulating Hormone } \\ \text { HTN } & \text { High Blood Pressure } \\ \text { LH } & \text { Luteinizing Hormone } \\ \text { WHO } & \text { World Health Organization } \\ \text { PAD } & \text { Diastolic Blood Pressure } \\ \text { PAS } & \text { Systolic Blood Pressure } \\ \text { RT-PCR } & \text { Real Time Polymerase Chain Reaction } \\ \text { SaO } 2 & \text { Oxygen Saturation } \\ \text { SHBG } & \text { Sex Hormone Binding Globulin } \\ \text { SARS-CoV-2 } & \text { Severe Acute Respiratory Syndrome Coronavirus Type } 2\end{array}$

